\title{
The Social Game between the Vote and the Democracy
}

\author{
Ángel Emilio Muñoz Cardona1,2 \\ ${ }^{1}$ Faculty Public Administration, Superior School Public Administration, Medellin, Colombia \\ ${ }^{2}$ VU University Amsterdam, Amsterdam, Netherlands \\ Email: angel@esap.gov.co, a.e.munozcardona@vu.nl
}

Received 11 March 2014; revised 12 April 2014; accepted 29 April 2014

Copyright (C) 2014 by authors and Scientific Research Publishing Inc.

This work is licensed under the Creative Commons Attribution International License (CC BY).

http://creativecommons.org/licenses/by/4.0/

(c) (i) Open Access

\section{Abstract}

From models of game theory, this paper attempts to question the nature collusion oligopolistic in imperfect markets vote and its true social benefit. Search to give reasons for ethical content which serves to change the electoral moral conduct and improves well-being in the public distribution of goods and services. In other words, answer the question, what should be the role of society in achieving better governance, or what must we do to improve as a community of voters? The priority challenge of contemporary societies is to instruct citizens for democracy, citizens with ability to choose and be elected. Educate political leaders, businessmen and society willing to work for the welfare of a nation without exception, not accepting corruption as a way of governing and being governed. That is the subject of this nodal essay research ${ }^{1}$.

\section{Keywords}

Participatory Democracy, Representative Democracy, Social Control, White Vote, Social and Civic Responsibility

\section{Introduction}

The Italian Norberto Bobbio (2000) says that vote as a mechanism of choice is not typical of monarchical societies which began to form in the wake of the English Enlightenment. The House of Lords aristocratic government in England, for example, decided to force arguments, what was best for the people. The members of the most powerful families elected the Lords. Actually the political decisions are taken by the Congress, Assemblies and Councils, which say to the executive-president, governor and mayor — what to do and how do it. The represen-

\footnotetext{
${ }^{1}$ This essay is one of the results of research on the New Public Management in Sabaneta Municipality, one of 10 municipalities of the Metropolitan Area of the Department of Antioquia, in the VU University Amsterdam with advisor PhD Alfons Van Marrewijk. 
tatives of such bodies of power are elected under the mechanism of the popular vote (Bobbio, 1997).

If we accept, the economy gain is higher when politicians occupy public office than that outside it, then in a democratic the political candidate to achieve power depends on the support it receives from the other members of the community supporters and councilors as well as their ability to celebrate agreements with groups of voters (Mill, 2001). Hence, it is plausible to conceive the relationship between voters and political candidates as a competitive relationship between buyers and sellers, where the offers or promises of programs are used as tools to win votes (Uribe, 2000). Such electoral competition by favoritism carries to different candidates to submit government programs little differentiation. Similarities explained as strategic opinion in the distribution of cluster voters to achieve a winning position.

The conformation of a large number of voters around the same proposal achieves better benefits. In other words, the higher the larger social group votes are bargaining power; the greater the chances of successful candidate have (Shubik, 1992a). But perhaps the most important achievement collateral is to unite wills. A community works and is interested in the welfare of your region, who have common interests, which gradually generates political culture, citizenship training, attachment or love for your region.

The obstacles to cooperating or forming social groups can be seen, in two different forms, on the one hand as the problem of deciding on the division of profit of cooperation and on the other hand, the problem of ensuring that the agreement is carried out correctly. The first problem has a solution in the kind of public good that conglomerates social group; therefore the gain is equal to the service it provides good conglomerate. The second problem has a possible solution through mandate revocation if the successful candidate does not comply with the agreement (Uribe, 2000). In other words, the solution to these obstacles can be accomplished by creating laws to enforce compliance with the agreements (Shubik, 1992a).

\section{The White Vote: A Sample Imperfect Political Culture}

In the fable, "Essay on the lucidity" the Portuguese novelist José de Sousa (Saramago, 2004) highlights the power of decision maneuver and every citizen, to exercise their right to vote in white. It is a wonderful fable, in which the novelist reflects on the reasons why we vote, when often neither candidate effectively addresses the social and economic needs of the population. A story that invites us to be critical of ourselves, to urge in our own ignorance citizens. How does a voter defend democracy but knows how to exercise it properly? Is this, how to return an appropriate instrument of social growth in an instrument bind of backwardness and violence? I think which is why the abundance of selfishness and lack of social sympathy or of a genuine political consciousness in what we do.

When man is aware of the choices you make, he's really free in his thinking and his political action. From there, the man can be moral as long as the man be educated properly on the sympathy of feeling with the other in other words responsible to others (Mill, 2002). From this perspective, the white vote or disagreement can be a mechanism for individual political pressure and solidarity, used to force a more responsible ethical attitude of candidates with the electors who choose to rely on them as doers of good public (Muñoz Cardona, 2009).

The white vote means the exercise of citizenship of an ethic of responsibility. It is the act of solidarity, through which citizens of a region come together in one mind sympathetic to reject the low quality of government programs or poverty of moral and ethical values of the candidates (Smith, 1997). To express this, the voters marked on the ballot, vote white.

In the Colombian Political Constitution (2005) the articles 103 al 106; 258 al 263 asked:

- The white vote is a form of electoral participation. It is a valid political position to prove the dissatisfactions against candidates.

- When the white vote constitutes a majority, of the total valid votes, the election shall be repeat only once.

- The white vote winning candidate no favors.

- The vote null and void not taken into account for counting of votes and is not interpreted as a sign of rejection, answer or rebellion.

- The white vote is an eloquent and censorship democratic candidates and political organizations that support.

According to what I read in the articles of the Political Constitution (2005), the only true in electoral practice, is that not the same voting in white that abstain from voting; because the blank votes not necessarily support the lack of solidarity of majorities, but yes abstentionism. For example: if elections for mayor of Sabaneta only 3\% choose to vote, the candidate benefited wins with $3 \%$ or less, so is the candidate most citizens not want. Otherwise the case if $100 \%$ of voters decide to elect: $33 \%$ for the Liberal candidate. $32 \%$ in favor of the Conservative 
candidate. $20 \%$ of invalid votes and $15 \%$ of white votes. Earn Liberal candidate elections by having the most votes. But if $20 \%$ of dissatisfied voters decide not to show his disappointment nullifying the ballot and choose white vote, then blank votes won with $35 \%$ and elections shall be repeated once, with different candidates.

That is the difference and perhaps the only importance of the white vote as democratic mechanism of opinion, forming citizen awareness and political culture ${ }^{2}$. The disadvantage is that white vote vetoes the candidate and not the party or political machinery that supports which only represents a setback in the electoral finance microenterprises (Barreiros, 1995).

The democratic dilemma in a social state of law is presented, when the white vote is no longer negligible and becomes representative, or to show a high percentage of social disenchantment. However, what happens, says writer and novelist (Saramago, 2004), if the white vote despite being significantly lost in electoral elections: How will affect the distribution of seats among political parties winners? Who occupies the seats do not can occupy the white vote, how to capitalize on social discontent without threatening democracy?

In Colombia, for example, the National Electoral Council, NEC, democratic downplays the white vote if loses elections, so its percentage gain is redistributed, consciously or unconsciously, between party lists who received most votes in elections. Look at it.

In Colombia there are two formulas for calculating the threshold of the collegiate bodies, one for Congress and one for Councils and Assemblies. For the appointment of congressmen threshold formula is $3 \%$ of the sum of the valid votes. For appointment of Councilors and Deputies threshold formula is the quotient electoral.

$$
\frac{\text { Sum total valid votes }}{\text { Total of seats to fill }}=\frac{\text { electoral quotient }}{0.5}=\text { Threshold }
$$

The difference in the use of both formulas is that the electoral quotient is more strict on the number of votes for the attachment of threshold that the second which harms the competitive market of the vote in the regions, but favors the consolidation or stability of the traditional political parties which form a collusive oligopoly. For example if we assume that the total valid votes in a municipality are 1,000,000 and the total number of seats to be filled is 21 the electoral quotient would be 47,619 so the threshold would be 95,238 votes. Note that if the total valid votes increases so grows the electoral quotient and therefore increases the threshold.

But, if on the contrary is to choose 100 members of Congress should take into account the total national vote. If the total valid votes nationwide was $13,000,000$. $3 \%$ would be 390,000 votes, the electoral quotient of 3900 votes and threshold would be 7800 votes; significantly increasing electoral competition between political parties for the highest number of votes. On one hand because it gains more political seats and strengthened as a party and on the other hand because once the list exceeds the threshold the Colombian State recognizes their legal status and helps them financially. In other words, the state funds the political campaigns of candidates.

After making the election and Indexes facts of valid votes, the formula for distribution of seats is done according to D'Hont indicator whereby calculating the proportional representation so (Bernardo, 2004):

- Divide the number of votes obtained by each list, first one, then two, then three and so on up out of all lists, the number of higher numbers which shall be equal to the number of seats available replace.

- Found the electoral quotient the last higher number of the series. All lists that have a number equal to or greater than the quotient will be the contributors of seats according to the total of votes achieved.

For a better insight, let us assume that in the city of Sabaneta is necessary to fill in the next election 21 seats for councilors. The total valid votes obtained in the different lists were 1,000,000 broken down as follows:

- The Liberal candidate 400,000 votes. $40 \%$ of total voting.

- Conservative Candidates list 250,000 votes. $25 \%$ of total voting.

- White votes 200,000 votes, $20 \%$ of total voting.

- CR list candidates 150,000 votes. $15 \%$ of total voting.

Since in the election results, the white vote did not win, then for the distribution of seats shall take into account the lists of parties that won the vote.

As the positions of seats needed to replace the Council of Sabaneta are 21, then, are ordered from highest to lowest, the first 21 numbers higher divisions obtained from different lists as well: 400,000; 250,000; 200,000; 150,000; 133,334; 125,000, 100,000, 83,333, 80,000, 75,000, 66,667, 62,500, 57142.8, 50,000, 50,000, 50,000,

${ }^{2}$ In 2011 Colombian elections for mayors, council and governor, in the municipality of Bello-Antioquia, for the first time won the white vote so that the elections should be repeating with different candidates. This story framework, because political confidence rebounded in the validity of the vote in white democratic mechanism, but above all, the importance of social union solidarity for the good of the community. 
$44,445,41666.67,40,000,37,500$; 36363.6. The quotient is 36363.6 to be number 21 in the series higher, as shown in Table 1.

Not excluded from the total valid votes the blank votes then the participation of political groups in the distribution of seats strengthens. The Liberal list, went from $40 \%$ of total vote to a $52.38 \%$ stake in seats. The Conservative list went from $25 \%$ of total vote to a $28.57 \%$ stake in seats. Radical Change list increased from $15 \%$ in total votes $19.05 \%$ stake in seats.

That is, all came gainful lists, with $20 \%$ of votes in white dividing by electoral weight (See Table 1 ). Therefore, the only way the white vote is significant, is when it wins elections, otherwise it becomes meaningless. Method of distribution of seats which contradicts the constitutional mandate stating that the white vote does not favor the winning candidate, because it is no so, because it does favor them, even at their party in achieving majority in collegiate bodies (Congress, Assembly or Council).

The great social paradox, posed by model white vote is as follows: although in a state of law the white vote is a democratic expression of dissent and moral imperative of political action leaders, stops being valid politically if not win elections, or when winning are preserved the political machines or electoral companies (Saramago, 2004). The white vote and own manifestation of a democratic and participatory state longer valid because lose elections and be meaningful unable to structural changes; on the contrary strengthens lists oligarchic political tradition (Kupferman, 1984).

Therefore, the market is an imperfect market vote because it is a strategic game that allows collusive oligopoly (Muñoz Cardona, 2009) ${ }^{3}$, the conclusion of agreements, political endorsements, and above because it ensures the permanence of tradition or oligarchic governments. In other words, the concentration of political power (Uribe, 2000).

If the white vote hasn't by law the ability to limit seats, or the action of political patronage of parties; then, democracy is a machine that not allowed to be questioned; that discredits the importance and validity of the vote as an expression of social construction (Bobbio, 1997).

For the white vote has power in the moralization of states, is necessary solidarity union voters, which is only possible, not as a plot but as citizen awareness of political responsibility (Mill, 2001). This is achieved if the voters, even unintentionally, act in solidarity, as if it were a cooperative social game, or non-zero sum (Smith, 1997). In the countries with low levels of awareness citizenship, the white vote does not teach democracy, by

Table 1. Definition of seats at council in Sabaneta town.

\begin{tabular}{|c|c|c|c|}
\hline & Liberal List $\mathbf{4 0 0 , 0 0 0}$ votes & Conservative List $\mathbf{2 5 0 , 0 0 0}$ votes & C.R List 150,000 votes \\
\hline Number of Votes divided by 1 & 400,000 & 250,000 & 150,000 \\
\hline Number of Votes divided by 2 & 200,000 & 125,000 & 75,000 \\
\hline Number of Votes divided by 3 & 133,334 & 83,333 & 50,000 \\
\hline Number of Votes divided by 4 & 100,000 & 62,500 & 37,500 \\
\hline Number of Votes divided by 5 & 80,000 & 50,000 & 30,000 \\
\hline Number of Votes divided by 6 & 66,667 & 41666.67 & 25,000 \\
\hline Number of Votes divided by 7 & 57142.8 & 35,714 & 21,428 \\
\hline Number of Votes divided by 8 & 50,000 & 31,250 & 18,750 \\
\hline Number of Votes divided by 9 & 44,445 & 27,777 & 16,666 \\
\hline Number of Votes divided by 10 & 40,000 & 25,000 & 15,000 \\
\hline Number of Votes divided by 11 & 36363.6 & 22,727 & 13,636 \\
\hline Percentage of participation of each list seats & $52.38 \%$ & $28.57 \%$ & $19.05 \%$ \\
\hline
\end{tabular}

Source: Illustrative model.

\footnotetext{
${ }^{3}$ The collusive oligopoly is a kind of poster with power companies try to limit competition forces, by establishing explicit or tacit agreements to fix prices, production, limit entry or prevent rivalry between them. Among the factors favoring collusion, we have the small number of companies; area agreements, product and time, the weak legal system, and the ease to detect violations in the agreements. The vote in Colombia market it is driven by electoral oligopolistic firms, which seek to consolidate their market power through the vote with a number of political seats, governors, mayors and president. To do fund their campaigns with public money and private hire image consultant's international prestige, invest in political marketing and purchasing alliances with major constituencies.
} 
contrast, is perpetuating political machines.

On the cover of the book "Democracy in America" published Trota say: "Political societies are, what they make laws, but to prepare them in advance to be feelings, beliefs, ideas, habits of heart and mind of the men who compose what the temperament and education have made them" (Tocqueville, 2010). If voters do not have the proper training of political citizenship with the other and with the other, the white vote will not be able to gain enough weight to moralize the action of political leaders, so that democracy will become increasingly imperfect in favoring the demagoguery, the guarantees and political patronage. In other words, the force lost programmatic vote for staking community unit growth and development of the region (Muñoz Cardona, 2009).

But if programmatic is vote the instrument of unity community around alternative or proposed public spending and investment that will enhance the growth and development of the region then the white vote is the complementary good, as is the conscious vote of acceptance to these proposals is the vote that excludes demagoguery and political clientelism. It's the vote that moralize politics.

\section{Pressure Groups and Political Parties}

To explain the importance of lobbyists (Muñoz Cardona, 2009), builds a theoretical model based on the Banzhaf index, where shows that the groups with the largest number of voters have more bargaining power than smaller turnout. What compels candidates agree groups of voters increasingly larger common interest, where they establish what the most pressing needs of its region are and what their contribution electoral voters. Maximizing profits the group as of candidates. It is should note, that this leads to a positive externality is to legitimize public power.

It is also possible to infer that small groups of voters are not significant to the triumph of a candidate, then regions of these groups fall in the economic and social backwardness. If each of the voters in a region votes according to your preference, and does not exist reasons that motivate them to join, or to fight, for the achievement of a common public good at all, then the democratic exercise lose its appeal communal good (Shubik, 1992a). This last statement becomes a great paradox, because if the candidate has no one to press in meeting their enforceable, then evade their commitments. That is, it is necessary for society: First, organized in groups, collectivizes by achieving coverage of public needs. Second, one mostly around one candidate, forcing the trustee to comply with enforceable. Third, keep the union citizen confidence around their institutions, which is possible with social pressure to enforce the candidate with its promises of social welfare (Muñoz Cardona, 2009).

It is necessary that society organized by community groups of voters able to negotiate public goods necessary for their region, thus guaranteeing the executions. That is, if the coalition candidate wins, then, must fulfill their promises of improvements in social welfare, but if you lose all voters who were with him also lose (Shubik, 1992b). Election results all show clearly the imperfections. In other words, the vote market does not necessarily is creator of political culture, as it can be a major factor of social imbalance because those communities that supported the losing candidate, they miss the opportunity to get the public goods that needed for their welfare (Tocqueville, 2010), (Mill, 1987).

Vote market leads to the formation of electoral microenterprises, which seeks revenue or profit, this is seats policies-ministries, embassies, councils, assemblies, senators, temporary jobs in public institutions; in other words, power institutional. Political representation reports image permanence and utilities to party offices (Uribe, 2000). The market voting is also a source of mongering and patronage because given the number of commitments made by the applicant with different communities, far exceed the investment budgets available, so that the political leader as well he did not want to be forced to default on the judgments (Kupferman, 1984).

The existence of a market vote makes it almost impossible to guarantee the honesty of elected as the elector, because of the possibility of trading votes and winning coalitions (Uribe, 2000). Where the plaintiffs to buy (voters), and the bidders sell (candidate) needs social and individual (goods and public office) ${ }^{4}$. We arrived at

\footnotetext{
${ }^{4}$ Spanish President Mariano Rajoy in 2011 enacted a congressional reform law, which seeks to deprive public officials many benefits popular vote. Law should also cover magistrates, congressional representatives, senators, and representatives, to improve public finances and moralize political activity. The reform proposals are: 1) The deputy will live only on their salary during his tenure. In addition, will not only retirement from the mandate. 2) The deputy contributes to Social Security. Everyone (past, present and future), currently the Congressional retirement fund regime will force Social Security immediately. 3) Congressional representative benefits participate in the Social Security system just like all other citizens. The pension fund will not use for any other purpose. 4) The deputy must pay your retirement plan, like all Spanish. 5) The congressional representative will vote for his or her own salary increase. 6) The deputy will present health insurance and participates in the same health system as other Spanish citizens. 7) The deputy must also comply with the same laws as the rest of the Spanish. 8) Serving in Congress is an honor, not a career. Members must fulfill their mandates (no more than 2 terms), then go home and seek employment.
} 
one of the typical problems of states and of contemporary societies: How to achieve the ideal shape of a political society? How to achieve a society of men more prone to search the general welfare?

The ideal case of a society clear and conscious of their real needs, could lead to full social union, the consensus, the debate for the general good, this is to evaluate and support mostly to the candidate better political agenda. This implies that the union citizen or groups ensures the success of the coalition and therefore greater social benefits, which would lead to a non-representative democracy but social participation, where people come together to make decisions based on the utilitarianism, that is, in the great social benefit (Neira, 1994). In other words, the formation of large clusters of voters around the same proposal is an instrument of pressure imposed by the dictatorship of the number and its near-absolute control (Shubik, 1992a).

\section{The Social Duty after Public Choice}

Achieved the candidacy it gives way to payments ${ }^{5}$ commitments to coalition groups during political election campaign. The ruler appoints his new cabinet and paid special favors. To facilitate understanding arises the model of game theory proposed by Italian (Domenech, 1998).

\subsection{Model Assumptions}

- The election campaign was conduct for President.

- The President is rational and has a proper conduct of homo economicus, so you will always seeking to maximize their individual profits.

- The President has two decision strategies:

1) Not legislate (NL) for the realization of public goods, because the society are obedient and fully complies with the payment of taxes, which are the main source of expenditure.

2) Lawmaking (L). Enact draft laws with due support from Congress, meet the Development Plan.

- The Society is organized into groups of voters with different interests or relating to their own community.

- The society has the following order of preference strategies:

1) Collaborate (C). If the president is honest and fulfills its enforceable.

2) No Collaborate (NC). If the President is dishonest and does not comply with the enforceable. Contribute as little as possible, avoid taxes.

\subsubsection{Formulation of the Model}

Under the assumption that the President has a selfish conduct, homo economicus, the order of preference, as the ordered pair (President, Society) is ${ }^{6}$ :

$$
(\mathrm{NL}, \mathrm{NC})=6 \gg(L, N C)=5 \gg(N L, C)=4 \gg(L, C)=3
$$

As the President of conduct homo economicus, choose first option (NL, NC), in other words, the strategy does not legislate, not execute, not submit bills to the legislature, postpone commitments and generate savings irrespective of how this society. Strategy becomes more profitable if you consider that the new ruler assumes the cabinet in a year with ongoing budget outgoing president, this facilitates the decision not to legislate ${ }^{7}$. If the President keeps decision NL is generated in social groups voting disagreements, criticism and threats of arrest that will change the decision of NL.

The second best option is ( $\mathbf{L}$, NC). The President will prefer to a citizens who do not believe in its mandate (evading taxes and no obey) make enforceable, legislative acts, agreements, tax amnesties, approve bills. Groups try to convince voters that he is committed to the welfare of all citizens and going to comply his campaign promises.

The third best option is (NL, C). If the President notes that the company believes in him and is willing to comply with their tax payments, that is work with the state then take advantage of the good social image having

\footnotetext{
${ }^{5}$ When it comes to payments we refer to payments bureaucratic jobs, create new jobs, tax cuts, public works, more welfare, etc., and the commitments made during campaigns.

${ }^{6}$ Mathematical notation means more preferable $>>\cdots$

${ }^{7}$ Ideally, the new president took office fiscal year beginning 1 January, so that the outgoing president finishes his enforceable, the realization of the projects was plan in the Annual Budget Plan, and may be judged by what he actually did or failed to do. This measure will prevent the wrong version of funds. Similarly, the incoming president should participate in developing the fiscal year budget that begins his rule.
} 
to avoid or divert spending towards private profit.

The fourth best option for President will be $(\mathbf{L}, \mathbf{C})$ he will prefer to acquire social commitments to a society willing to obey always. Option is less preferred for him because supposed to spend the entire budget of the investment plan in meeting all its commitments and therefore not generate savings for private benefit or private gain.

Let's assume that the Society has a group behavior. That is, each member approves and supports the benefit of cluster they represent and not shown have interest in supporting or defending interests of other groups (De Waal, 2011). Each group of voters believe in the goodwill of the president-elect so they contribute to the payment of taxes are willing to abide by the rules and obey them (Domenech, 1998).

The different groups of voters established the following order of preference, as the ordered pair (President, Society).

$$
(\mathrm{L}, \mathrm{C})=6 \gg(N L, N C)=5 \gg(N L, C)=4 \gg(L, N C)=3 .
$$

The first choice for the constituency is $(\mathrm{L}, \mathrm{C})$. The Society prefers to play to obedience, because they believe in the goodwill of the president in meeting payments or enforceable. Therefore if the president is correct and meets the covenants the groups also undertake to meet tax payments facilitating public spending.

The second best option for the constituency is (NL, NC). They prefer not to obey not submit voluntarily if the president does not comply with the agreement on the campaign trail, in other words with the payment of tax.

The third best choice for the constituency is $(\mathrm{NL}, \mathbf{C})$. Groups of voters will prefer willingly obey well the president did not fulfill its commitments provided to achieve a certain social harmony. Renounce their political power for the sake of social and civil stability.

Fourth groups of voters will prefer (L, NC). The last thing they will want to do is fall into irrationality upset the institutional and social structures, in other words the worst for the group of voters does not work despite the president keeps his promises.

Combined orders preferences behaviors between the President and the Society is obtained the following payoff matrix, Table 2.

\subsubsection{Understanding the Model}

According to the decision strategy based on the principle of maxi-min, this is where the maximum and the minimum value are equal (See Table 2). The balance point of the game for the President is to count on social obedience of the governed that they dutifully pay their tax obligations though he does not comply the commitments made in the field or with the development plan, in other words take the political and personal gain rather than the art of making the public good. Observe two things:

First, if the President knows that Society is correct with their tax payments then he will prefer not to legislate as he has the possibility of obtaining a minimum gain equals four, but if he legislates his profit will be less or equal to three, (See Table 2). Therefore, if the president has a conduct of selfish behavior (selfishness, no social or maximizing his private benefits) then he will prefer not to legislate. (Smith, 1997: p. 551) ${ }^{8}$.

Second, to continue the political game, the President is preferable strategy would "not legislate" since although Society is organized in groups, is divided inside (See Table 3). Therefore, the Society ends opting for a selfish behavior (Hobbes, 1994). They get tired of being right, seek to evade taxes, help plunder the budget sup-

Table 2. Payment matrix.

\begin{tabular}{|c|c|c|c|}
\hline \multirow{4}{*}{ President } & \multicolumn{3}{|c|}{ Society } \\
\hline & & $C$ & $N C$ \\
\hline & $N L$ & $(4,4)$ & $(6,5)$ \\
\hline & $L$ & $(3,6)$ & $(5,3)$ \\
\hline
\end{tabular}

Source: Illustrative model.

${ }^{8}$ For the father of economics is natural the existence of moderate selfishness (self-love) in humans. Every man seeks for himself what is good or pleasing. Opposite case occurs with pure selfishness or not moderate (selfishness), which aims at the exclusive importance of personal feeling regardless of the other. Feelings of sympathy that are not even possible in a society of merchants, because of being the mistrust suspicion, anger at injustice and past experiences would not allow more exchange. 
Table 3. Payment matrix for president and for society.

\begin{tabular}{|c|c|c|c|c|c|c|c|c|}
\hline \multirow{4}{*}{ President } & & \multicolumn{7}{|c|}{ Society } \\
\hline & & $\mathrm{C}$ & $\mathrm{NC}$ & MIN & & $\mathrm{C}$ & $\mathrm{NC}$ & MAX \\
\hline & NL & 4 & 6 & 4 & NL & 4 & 5 & 5 \\
\hline & $\mathrm{L}$ & 3 & 5 & & $\mathrm{~L}$ & 6 & 3 & \\
\hline MAX & & 4 & 6 & 3 & MIN & 4 & 3 & 6 \\
\hline
\end{tabular}

Source: Illustrative model.

port corruption. Thus, the ethics of a society divided into groups degenerates due ethics of social altruism.

Given a President who does not-it is not honest-the criterion of individuality or power group number involves not work with this president, on the contrary with political deception ethically justify civil corruption (Hobbes, 1994). Evade tax payments. It is a society seeking, bribery, lying, cheating. Even when community leaders make oversight control do it for personal gain and not social (NL, NC).

As a result the benefit of the president up to six and the society up to five. Society, to evade taxes also increases their disposable income and consumer power in the very short term. That is, the policy is passed as a virtue to vice, degenerate institutions and culture of deception and consolidates political trap (Tugendhat, 1993) ${ }^{9}$.

We can conclude that under the assumptions of a president with behavior homo economicus and a society divided into groups or local interests that are no integrated. In the Table 2 the equilibrium point of the game is presented there where the president does not legislate and society does not comply their tax payments. Income or gain is maximum and equal to eleven: $(\mathbf{N L}, \mathbf{N C})=\mathbf{1 1}^{10}$. What, we can do? Will be that society is hopelessly doomed to suffer dictatorship unsupportive of selfishness? Who said Hobbes (1994).

\subsection{The Social Paradox of Political Duty}

However, it will change the course of a society divided into groups by the behavior of a society of solidarity, united around a common global social sense, then, the equilibrium point of the game changes (Rousseau, 1988). Since the behavior of society would build on the philosophical principles of fraternity and solidarity enlarged which will help to improve distributive social justice. This is requires the implementation of better public policies (Aristoteles, 2004) $)^{11}$.

If society as a whole bind is more strategic, more unpredictable in their actions to the president, more threatening because is vigilant and it requires transparency of public administration. Because ceases to be acceptor and becomes more active, which leads her to improved social and political norms existing in good of all the community, in other words, to think as a whole (Rousseau, 1988).

To prove this, game theory raises another way to find the balance, in which players seek to be unpredictable in their behavior (Muñoz Cardona, 2009).

Taking the values President for the player of the Table 3. Let $\mathbf{P}$ and $\mathbf{Z}$ probabilities of occurrence of events for the rows of the matrix of society, where $\mathrm{P}+\mathrm{Z}=1$.

So that $0<P<1 \wedge(1-\mathrm{P})=\mathrm{Z}$.

$$
4 \mathrm{P}+5(1-\mathrm{P})=6 \mathrm{P}+3(1-\mathrm{P}) \Rightarrow 4 \mathrm{P}+5-5 \mathrm{P}=6 \mathrm{P}+3-3 \mathrm{P} \Rightarrow 4 \mathrm{P}=2 \Rightarrow \mathrm{P}=1 / 2 \wedge(1-\mathrm{P})=\mathrm{Z}=1 / 2
$$

\footnotetext{
${ }^{9}$ Without fear of being wrong, think Colombian reader, for example, in the most notorious corruption case in early May 2007 in the department of Chocó, where three children died of malnutrition and lack of medical resources for public attention. Done that shocked the country and forced the rulers of that department explain. It was find that, if resources had been deliver, but did stolen, by the councilors of the municipality. Politicians involved in the robbery accomplices were convict of murder. The community of Choco seems to be accustomed the continuous theft of public resources for health, education and social welfare.

${ }^{10}$ The solution of the game due to the elimination of dominated strategies. Yes legislate for strategy is dominated by the president not to legislate, then, not to legislate is a strategic decision optimal. In addition, by having society interest group behavior, but not social, collaborate eliminate dominated strategy, since no work will generate higher profits.

${ }^{11}$ In Book VII of the Politics, Aristoteles (2004) argues that democracies vary according to its constituent citizens, and institutions that support it. The first principle of a democratic government is the freedom to allow each other to live as he pleases. The second the removal of public charges. The third integrate all members of society Hence, that education and good manners: respect and prudence are essential as Adam Smith affirmed.
} 
Taking the values Society for the player of the Table 3. Let $\mathbf{s}$ and $\mathbf{t}$ probabilities of occurrence of events for the columns of the matrix of society where $\mathrm{s}+\mathrm{t}=1$.

Such that $0<\mathrm{s}<1 \wedge(1-\mathrm{s})=\mathrm{t}$

$$
4 s+6(1-s)=5 s+3(1-s) \Rightarrow 4 s+6-6 s=5 s+3-3 s \Rightarrow 4 s=3 \Rightarrow s=3 / 4 \wedge(1-s)=t=1 / 4 .
$$

The statistical expectation or average value of the strategic game is equal to:

$$
\begin{aligned}
& 4 \times 3 / 4+5 \times 3 / 4+6 \times 1 / 4+3 \times 1 / 4=9 \\
& 4 \times 1 / 2+5 \times 1 / 2+6 \times 1 / 2+3 \times 1 / 2=9
\end{aligned}
$$

This implies that the average gain value of the game is nine. Citizenship played in four $75 \%$ chances obedience social strategy, will comply "voluntarily" with their tax payments, and will play $25 \%$ strategy no social obedience. The Society promulgated by a reduced role for the state and require the President fulfillments to collaborate again. The President on the other hand, will play half of the time to legislate, and the other half not to legislate. What requires of the society a to remain united around the common good, to seek consciously social welfare and, therefore to control the action the economic selfishness of president, to be vigilant in public spending, to investigate how it spends public money, in other words, to be more participatory socially and politically (Cortina, 1999).

A society of altruistic behavior, committed to the welfare of all citizens, this political consciousness is shall accept as the only way of action of the President and every ruler, compliance with government program (Muñoz Cardona, 2009). Society shall require the trustee administrative responsibility in the implementation of the development plan.

As the strategy ( $\mathbf{L}=3, \mathbf{C}=6$ ) gives a nine social benefit (equal to the average value of the game for society of the Table 2), it becomes optimal in the utility function.

The President should be honest and comply with the agreement on the campaign trail, perform the executory. The Society will play to be successful, to make a social control for the benefit of the entire region and not a locality, and comply "voluntary" the payment of taxes. For it is necessary, effectively compromising the parties, creating a political culture very wide and rich in civic social values which, constitutes a great challenge in the role of politics ${ }^{12}$. Promote in the words of John Stuart Mill, universal education in civil and political values of democracy (Mill, 2002: p. 85), (Guisán, 1995) $)^{13}$.

In other words, organize political institutions, so that the bad trustees for absence of social control in the accountability, they facilitate continuity in damages economic and moral to society in such a way that they cannot continue using the vote and democratic institutions for private purposes of the election micro enterprises For this it is necessary that citizens cease to be indifferent, regain confidence in political institutions and become permanent players in the political game. Society, as a living organism responsible for their own future, must assume the role of vigilant of political action, limiting corporate selfishness of clientelism and political machines. Society as most of beings feel and lacking which must appropriate policy instruments for the promotion of well- being or general utility, through community democracy, participatory and direct (Komadina, 2010) ${ }^{14}$.

The Bolivian Jorge Komadina Rimassa, looks at the mechanisms of participation civil and social control a high democratizing potential, that although politicizes localities not becomes corrupt, by the contrary they are filled of social presence in the field of the participatory, they created new forms of language Community. The society enriches through processes of accountability-sanction or accountability-recognition.

Before the use of the term accountability of public administration, PhD Nuria Cunill Grau says it's inaccurate,

\footnotetext{
${ }^{12}$ It starts to believe that the will of many is stronger than the will of one. That a highly political society formed in social values, with a stronger civil ethics will not allow dishonest practices of their rulers. In turn, the rulers who are also the product of the society in which they operate are more likely to practice public good rather than individual.

${ }^{13}$ Read also the comments made by the professor, Esperanza Guisán, in the introduction to the text, pages 21-22. The Englishman, John Stuart Mill, conceived the social nature of man, in the same sense as Aristoteles (2004) in Politics, on which men grouped towards the same goal of a common or general happiness, which every man becomes one with the interests of others. The desire or the will to be happy is express in part in the solidarity of the one and the other. This solidarity engenders the feeling of closeness and from it man, not only is aware of him, but also is aware of the similarity of the other, is aware of his consciousness.

${ }^{14}$ Jorge Komadina Rimassa, born in Bolivia-Cochabamba in 1959. Sociologist and political analyst. It is responsible for the thematic line "Transparency" of the Center for Applied Studies in Economic, Social and Cultural Rights (CEADESC). He has published several works on political and cultural themes, including "The Power of Political Movement” (PIEB, 2007) and "Budget Transparency Report on Prefectural Cochabamba” (CEADESC, 2008). Part of the "Red Cochabamba Departmental Transparency”. gkomadina@ceadesc.org.
} 
because it remains unclear whether it is in the moral sense typical of a civic consciousness or in the legal sense own the synonym accountability (Cunill \& Ospina, 2000) that is, to answer for $(\cdots)$ to comply with $(\cdots)$. However, from a holistic point of view, the ruler's power rests on legitimate power given by public choice and responsibility of moral conscience to fulfill his promise and the agreement in terms of governance or even from a neoclassical view of the citizen-customer economics, legal and moral responsibility may be two words complementary and not exclusive (Berlin, 2000).

For Nuria Cunill, recent trends of institutionalization of social control over public administration in Latin America forced to wonder about who, what, how and on what habitat social control can be exercised by society groups, without compromising its effectiveness and democracy itself (Cunill \& Ospina, 2000). That is, how cohesive and how informed are for citizen oversight groups. How groups are trained to understand the importance and meaning of public good, as we questioned the economist and philosopher of Antioquia (Muñoz Cardona, 2010).

However, when we talk about public resources and social control of public expenditure management, citizen oversight or community of citizens that make institutions social control, they should first ask themselves; what are public goods, and what we understand by goods public? What is the nature of public goods and hence public spending? They should first ask themselves. What we understand by democracy? Of clarity that is available on these concepts depends to a large extent, the good performance of the institutions of social control; even true distributive public policies for social inclusion; This validates the success of democracy and good governance (Mill, 2002), (Nousbbaum, 2010), (Muñoz Cardona, 2009).

\section{Conclusions}

While in the market for goods and services, individuals improve their profits with individuality in the market of the vote, the association is required. Therefore, the paradox of social game between voting and democracy is: although the community can reach higher utility by playing the strategy $(\mathbf{N L}=6, \mathbf{N C}=5)$, obtaining a social payment of 11, it leads to the loss of civil values, social distortion, the political practice as vice and not a virtue. A commonplace is back nepotism, corruption, evil version of funds, fraud, lying, cheating and deception policy (Mandeville, 1982).

However, there is a second best social equilibrium $(\mathbf{L}=3, \mathbf{C}=6)$. In which the gain is smaller, but citizenship is done and wellbeing is constructed for all (De Waal, 2011). An investment only makes sense if you think about the country you want, in the welfare of future generations (Rousseau, 1988).

Every citizen must ask yourself. Do I want to live in a country with participatory democracy, with a ruler committed to meeting its executory (Maquiavelo, 1995) ${ }^{15}$ ? Or do I prefer living in a state of representative democracy, with ruling not very committed to meeting its executory (Mandeville, 1982)? Another way to ask the same question would be: Do you want to live in a country based on a social welfare state, where it enjoys a lower socio-economic utility today, but with the expectation that in the future this will be a better country for their children in political, economic and social development? As Rousseau would say, with the need to "look for a viable political state model as close as possible to the" Natural Piety "of men, an organization of social lifeleast damaging civil as possible, in a word the lesser evil. This is the purpose of the social contract" (Rousseau, 1988).

Do you want to live in a country based on the rule of representative democracy, where you can enjoy a higher socio-economic utility today, but with the certainty that in the future this will be a bad country for their children in development political, economic and social? A country that would say Mandeville in his satire: "Let, then, complain: fools only strive to make of a great honeycomb, a honeycomb honor. Fraud, Luxury and Pride must live while we enjoy its benefits. It is also beneficial when vice justice so pruning and limits, and even more, when people aspire to greatness, so necessary for the state as is the man to eat, virtue alone cannot make Nations live lavishly as they have to get rid of honesty as acorns" (Mandeville, 1982).

\footnotetext{
${ }^{15}$ In the book the "Prince” of Machiavelli, defines human freedom as the human capacity to lead and redirect the course of natural and social events to where the man wants. Thomas Hobbes in his book "Leviathan" cautions that consistent voluntary agreement to end the violent competition is also a property manifested in human nature. Reason dictates a natural law that leads men to replace violence with peace, security and insecurity eventually to negotiate their freedom with the social order of concerted political authority. Rousseau in the "Social Contract” states that when all individuals in a society join forces in order to guarantee grouping satisfaction naturally needs, but how to preserve the Freedom. Rousseau says, “ $\cdots$ giving her strength not to another if not the entire community: to alienate everyone is not given to anyone and in continuous last giving himself to himself”.
} 
Participatory democracy or representative democracy? What kind of democratic government would rather the citizens of a country have, or what other form of government are ready to build? The society itself chooses with its form of political participation because democracy is a social truth in construction continues (Sen \& Kliksberg, 2007). It is an ethical way of living in society. No is democratic but rather has experienced the value of solidarity, altruism, sympathy, social responsibility, loves the other, respects to resources and common goods and their value for future generations (Muñoz Cardona, 2006). While the values of democracy are indifferent and strange to the bulk of the population, it will prevail corruption, fraud, nepotism, and with them social backwardness; as said professor Maria Cristina Motta: "Corruption is a problem of social ethics, not of individual ethics", is another way of governing and being governed, another way to achieve a precarious social order.

\section{References}

Aristoteles (2004). Política. Porrúa: Vigésima Edición.

Barreiros, R. (1995). Lecturas de sociedad y política. Santiago de Cali: Universidad del Valle.

Bernardo, J. M. (2004). An Alternative to Jefferson-D'Hondt Rule. España: Universidad de Valencia.

Bobbio, N. (1997). La teoría de las formas de gobierno en la historia del pensamiento político. México: Fondo de la Cultura Económica.

Bobbio, N. (2000). Estado, gobierno y sociedad. Por una teoría general de la política. Colombia: Fondo de la Cultura Económica.

Berlin, I. (2000). Cuatro ensayos sobre la libertad. España: Alianza.

Cortina, A. (1999). Los ciudadanos como protagonistas. Barcelona: Círculo de Lectores.

Constitución Política de la República de Colombia (2005). Bogotá. Colombia: TEMIS.

Cunill, N., \& Ospina Bozzi, S. (2000). La responsabilización en la nueva gestión pública latinoamericana, sociabili- zación por el control social. Responsabilización por el Control Social. Buenos Aires-Argentina. Consejo Científico CLAD; BID; EUDEBA.

De Waal, F. (2011). La edad de la empatía: ¿somos altruistas por naturaleza? España: Tus Quets Editores.

Domenech, A. (1998) De la ética a la política. Barcelona: Tecnos.

Guisán, E. (1995). Ch 10, Introducción a la Ética. Madrid: Cátedra, 377-409.

Hobbes, T. (1994). El Leviatán. Barcelona-España, Altaya: Grandes Obras del Pensamiento.

Komadina, R. J. (2010). El debate sobre el control social. Bolivia: CEADESC.

Kupferman, F. (1984). La corruption dans la république. Révisa Corruption, 31, 188-196.

Mandeville, B. (1982). La fábula de las Abejas o los vicios privados hacen la propiedad pública. México: Fondo de Cultura Económica.

Maquiavelo, N. (1993). El Principe. Barcelona-España, Altaya, Grandes Obras del Pensamiento.

Maquiavelo, N. (1995). The Prince. London: Penguin Classics.

Mill, J. S. (2002). El Utilitarismo. Madrid: Filosofía, Alianza.

Mill, J. S. (2001). Considerations on Representative Goverment. Madrid: Editorial Alianza.

Mill, J. S. (1987). Principles of Political Economy. London: Longmans, Fairfield: A. M. Kelley.

Muñoz Cardona, Á. E. (2009). Ch, 3, Macroeconomía y desarrollo. Colombia: Universidad de Antioquia.

Muñoz Cardona, Á. E. (2010). Del principio de simpatía y de la ética de la solidaridad. Medellín: Universidad Pontificia Bolivariana. Trabajo de investigación laureado con el Magna cum-laude.

Muñoz Cardona, Á. E. (2006). Del sentimiento de la prudencia o la mano invisible de la moral. Lecturas de Economía, Medellín: Universidad de Antioquia, julio-diciembre, número 65, 223-240.

Neira, A. (1994). No ceder Ante los Narcos. Colombia, Revista Cambio 16, número 79, Dic. 12 a 19, 25-37.

Nousbbaum, M. (2010). Sin fines de lucro. Por qué la democracia necesita de las humanidades. Buenos Aires: Katz Editores.

Rousseau, J. J. (1988). El Contrato Social. Barcelona: Tecnos.

Saramago, J. (2004). Ensayo sobre la lucidez. Madrid: Alfaguara.

Sen, A., \& Kliksberg, B. (2007). Primero la Gente: Una Mirada desde la ética del desarrollo a los principales problemas del mundo globalizado. Barcelona: Ediciones Deusto. 
Smith, A. (2005). An Inquiry into the Nature and Causes of the Wealth of Nations. University Park, PA: Pennsylvania State University Press.

Smith, A. (1997). Teoría de los Sentimientos Morales. Madrid: Alianza Editorial.

Shubik, M. (1992a). Teoría de los juegos en las Ciencias Sociales: Conceptos y soluciones. México: Fondo de Cultura Económica.

Shubik, M. (1992b). Economía Política: Un enfoque desde el punto de vista de la teoría de los juegos. México: Fondo de Cultura Económica.

Tugendhat, E. (1993). Lecciones de ética. Barcelona: Gedisa.

Tocqueville, A. C. H. C. (2010). Democracia en América. Barcelona: Trotta, Liberty Fund.

Uribe, R. (2000). La Hacienda Pública. Medellín: Editorial Marín Vieco, Universidad de Antioquia, Facultad de Ciencias Económicas, Contaduría, Cuadernos Contables, Colección Quipus número 2, Separata. 
Scientific Research Publishing (SCIRP) is one of the largest Open Access journal publishers. It is currently publishing more than 200 open access, online, peer-reviewed journals covering a wide range of academic disciplines. SCIRP serves the worldwide academic communities and contributes to the progress and application of science with its publication.

Other selected journals from SCIRP are listed as below. Submit your manuscript to us via either submit@scirp.org or Online Submission Portal.
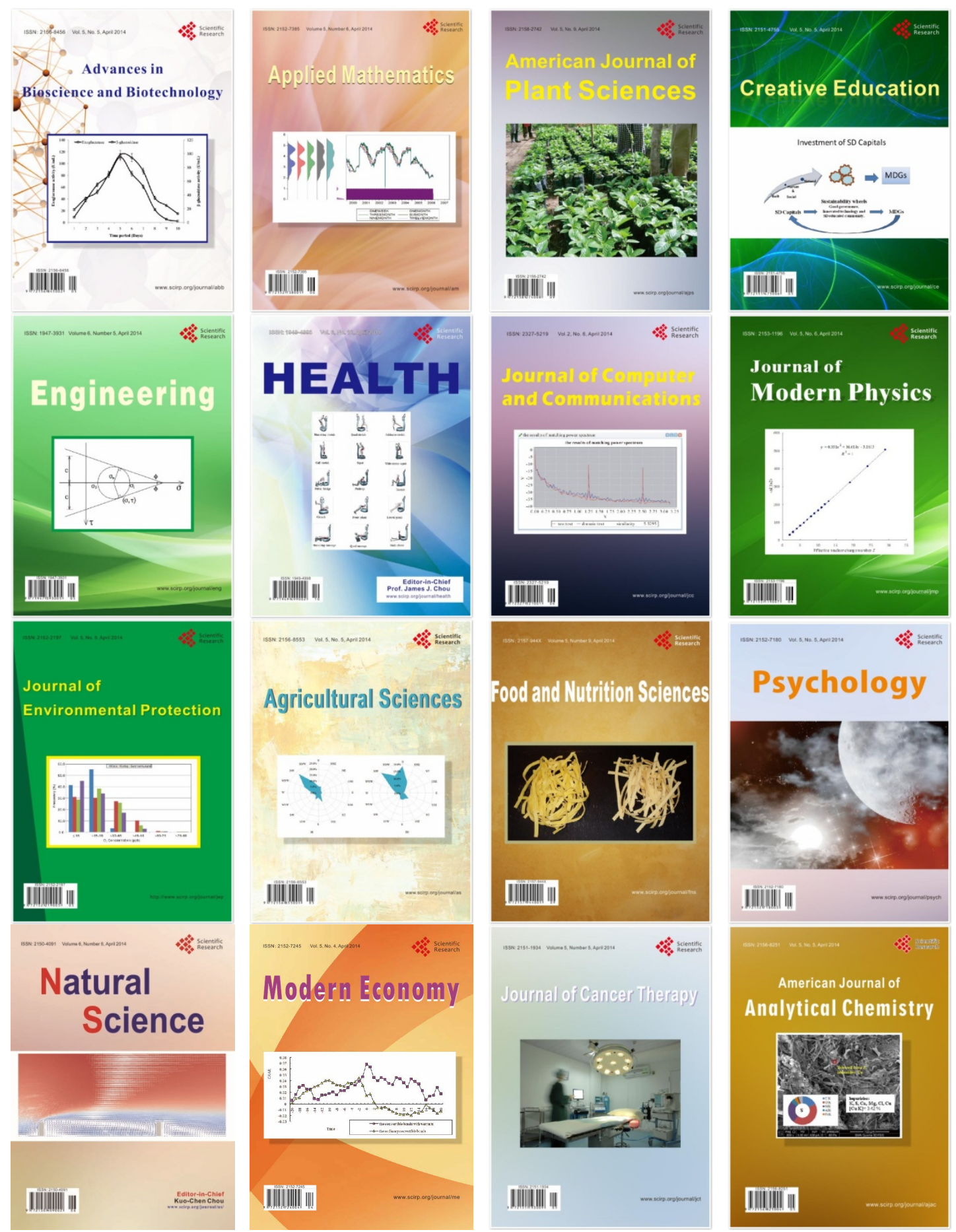